\title{
Indonesian and English Lexical Metaphoric Expressions Used In Online Competition News Text
}

\author{
Siti Tarwiyah \\ FITK UIN Walisongo Semarang \\ sititarwiyah98@yahoo.co.id
}

\begin{abstract}
The subject of this article deals with discourse semantics. The focus of its description is metaphoric expressions used to express competition news in online media. Based on some theories about metaphor, the writer tries to search for kinds of metaphoric expressions used and the reasons behind the use of the expressions. The result shows that English and Indonesian language use lexical metaphors with three specifications, i.e. anthropomorphic, animal, and synesthetic. The choice of specific lexical metaphoric expressions is related to situational and cultural aspects.
\end{abstract}

Key words: Metaphor, Online Media News, Cultural Aspects

\begin{abstract}
Abstrak
Subyek artikel ini berhubungan dengan semantik wacana. Fokus deskripsinya ialah ekspresi metaforis yang digunakan untuk mengungkapkan berita kompetisi di media online. Didasarkan pada beberapa teori tentang metafora, penulis mencoba untuk mencari jenis ekspresi metaforis yang digunakan dan alasan di balik penggunaan ekspresi tersebut. Hasil penelitian menunjukkan bahwa Bahasa Inggris dan Bahasa Indonesia menggunakan metafora leksikal dengan tiga spesifikasi, yaitu metafora antropomorfik, metafora binatang dan metafora sinestetik. Pilihan ekspresi metaforis leksikal tertentu berkaitan dengan aspek situasi dan budaya.
\end{abstract}


Indonesian and English Lexical Metaphoric Expressions Used In Online Competition News Text

Kata Kunci: Metafora, Berita Media Online, Aspek Budaya

\section{Introduction}

Every nation or community has its own ways to express information, thought, idea, attitude, and stand point. This is in line with Saussure opinion (in Crystal, 1993:407) that the relationship between signifier (form) and signified (meaning) is arbitrary. This arbitrariness mainly depends on culture of the society and how they see phenomena around them. Javanese people consider their interlocutors in choosing which speech level to use, Ngoko, Kromo, or Basa. English people see the importance of time through the use of tenses. Eskimo differentiate five kinds of snow represented by five terms. Indonesian people see the difference among padi, beras, and nasi which are called rice in English.

On the other hand, language also influences choices of interpretation to things around the language users. Sapir (in Hodge and Gunther, 1993:210) said, “... language habits of our community predisposes certain choices of interpretation. In Indonesian language padi is different from beras and nasi. All of which are called rice in English. This results in an interpretation that all those three things are different that must be treated differently in accordance with their functions.

Metaphor, as one of figurative languages may be seen as another example of the difference in language use. Every speech community often has distinctive symbols to refer to certain referents. English people may say $d r$. Yusuf is a butcher, pass with flying colors, feel blue, which cannot be found in Indonesian language. 
The definitions of metaphor from some experts seem varied. Metaphor or figure of speech is "a word or phrase which is used for special effect, and which does not have its usual or literal meaning" (Richards, 1990: 105). The Greek translation of metaphor simply means 'transfer'. It is a transfer because it replaces a certain word which cannot fully express the writer's mind. Johnson (1972:26) defines metaphor as "carry beyond". It is an expression that literally denotes one thing but at the same time it is used to refer to something else. The changing of the referent is influenced by its context. Metaphor is based on perception of similarities between two references, i.e., thing which is being talked and which is being compared (Ullmann, 1972:213). It is a normal thing that we see some same metaphoric expressions in many languages as far as they have clear analogies (1972:238)

Metaphor is a variation of language which can be found in any language. Lakoff and Johnson in Metaphors We Live By admits this phenomenon. They say that metaphors is used both in literature and in daily language in any language and dialect (in Hatch and Cheryl, 1995:87). Some examples of universal metaphors are analogizing darkness with sadness or bad luck (Cirlot in Abdul Wahab, 1991:15), catch or grab means understand (Ullmann, 1972:238), assuming heat as anger (Lakoff and Johnson in Hatch and Cheryl, 1995:96).

Meanwhile, Harimurti says that is the use of a certain word or expression for another object or concept based on analogy or similarities (1983:106). Metaphor is an analogy that compares two 
Indonesian and English Lexical Metaphoric Expressions Used In Online Competition News Text

things directly (Gorys Keraf, 1987:139 and Anton M. Moeliono, 1988:580).

Abdul Wahab, an Indonesian linguist who has observed metaphoric problems, defines metaphor as an expression whose meaning cannot be grasped directly from its form because the meaning is predicated on the expression. The meaning is formulated based on understanding and experience of the thing meant to refer something else (1995:72).

Metaphor is a creative power of language. It may give the freshness in language, avoid boredom, revive dead things (language), and actualize things (language) which are paralyzed. That is why metaphoric expressions are mainly used in literature with the creativity of men of letters in processing language (Edi Soebroto, 1986:46).

Metaphoric concept is actually based on relativism paradigm that is figured by Edward Sapir (1921) and Whorf (1956). According to this school, meaning is the result of mental processes. This is due to unseparated relationship between human and their society, which influences human's thought about their life (Sapir in Sampson, 1980:82-83).

Metaphor is an important in our conceptual system. It may also reinforce social values of its user. "Metaphors are fundamental parts of our conceptual system. We could not eliminate them from our vocabulary or our press.” (Nelson in Pangestuti, 1997:183) “... By framing an issue in a particular way, metaphors reinforce certain social values...." (1997:182) some rude or taboo expressions tend to be 
metaphorized in order to be more polite or cultured. Indonesian people prefer using pekerja seks komersial to cabul, keluarga pra-sejahtera to keluarga miskin that are more euphemistic.

Every nation or language community has different ways of expressing information, idea, attitude and stand. Saussure said that the relationship between form (signifier) and meaning (signified) is arbitrary (Crystal, 1993:407). This difference depends on the culture of the community and the way they view phenomena around them. Javanese people often take the status of their interlocutor into account, which is then used as consideration whether to use krama or ngoko. The use of tense in English asserts the importance of time within English people. People in Eskimo have more than five words to refer to different snow. Indonesian people have padi, gabah, and beras, while English people only have rice. All these expressions and norms of speech are tightly related to the view of each people on the realities around them.

The principle of arbitrary can also be seen in the use of metaphor. Besides its universal every language community often has different symbol to refer to a certain referent. English people has no cry over the spilt milk, which is expressed as nasi sudah menjadi bubur in Indonesian language. Chagga speakers see a sexy woman as lilya 'oven' but Indonesian people see this woman as a guitar.

As a kind of creativity of language use, metaphors are interesting to be observed. In which domain it should be looked? Searle claimed that metaphor is an utterance meaning rather than sentence meaning and should be investigated pragmatically (Morgan, 
Indonesian and English Lexical Metaphoric Expressions Used In Online Competition News Text

1980:139). Abdul Wahab asserted that social and cultural context, human perception, comprehension, and sometimes myth and symbolism should be taken into account when we discuss metaphor (1995:93). This is to say that enough knowledge about this world is highly recommended in the discussion.

Metaphor has something to do with human perception system of this universe and feeling (Hatch and Cheryl, 1995:95). Suggesting the similar argument, George Lakoff and Mark Johnson (1980) say,

"... Metaphor is not just a matter of language, that is, of mere words. We shall argue that .... Human thought processes are largely metaphoric. This is what we mean when we say that human conceptual system is metaphorically structured and defined.” (In Abdul Wahab, 1995:76)

Lexical metaphor is identified from the use of a certain word that denotes a certain thing or reality to refer to another thing or reality. The word flooded in in the protest flooded in is an example of lexical metaphor. Flooded usually refers to a large quantity of water covering an area that is usually dry. The congruent expressions to describe a big protest are Protest were received in large quantities and even very many people protested.

\section{Research Methodology}

\section{a. Object of the study}

The object of this study is online competition news text uploaded from October to December 2014. 


\section{b. Unit of Analysis}

This research is focused on metaphoric expressions used to express competition news. The analysis involves lexemes in its context or grammar. It is realized at the lexico-grammar strata. According to Eggins (1994: 82), if the stratum of language to be analyzed is lexico-grammar, the unit of analysis is clause.

\section{c. Technique of Data Collection}

The data of this study was collected by downloading online competition news text uploaded from October to December 2014.

\section{d. Technique of Data Analysis}

The data was analyzed by using the following steps:

a. Reading the news

b. Segmenting the news into clauses

c. Identifying the metaphoric expressions

d. Identifying semantic relations between symbol (metaphoric expressions) and referents.

e. Interpreting the influence of cultural aspects toward the use of symbols.

\section{Discussion}

\section{Anthropomorphic Metaphors}

The tables below shows Indonesian and English lexical metaphors used in Indonesian online competition news. 
Indonesian and English Lexical Metaphoric Expressions Used In Online Competition News Text

Table 1

Indonesian Anthropomorphic Metaphors

\begin{tabular}{|l|l|l|l|}
\hline No. & Expression & $\begin{array}{l}\text { The Change from } \\
\text { Referent } \rightarrow \\
\text { Symbol }\end{array}$ & Meaning \\
\hline 1. & $\begin{array}{l}\text { singkirkan } \\
\text { unggulan } \\
\text { pertama (Ib1) }\end{array}$ & $\begin{array}{l}\text { opponent/people } \\
\rightarrow \text { unused thing }\end{array}$ & defeat \\
\hline 2. & $\begin{array}{l}\text { menyingkirkan } \\
\text { unggulan } \\
\text { pertama (Ib3) }\end{array}$ & $\begin{array}{l}\text { opponent/people } \\
\rightarrow \text { unused thing }\end{array}$ & defeating \\
\hline 3. & $\begin{array}{l}\text { mengukuhkan } \\
\text { provinsi ibu kota } \\
\text { negara (Id2) }\end{array}$ & $\begin{array}{l}\text { winning } \rightarrow \text { title } \\
\text { domggeser } \\
\text { (Id3) }\end{array}$ & $\begin{array}{l}\text { decide as the } \\
\text { winnerl }\end{array}$ \\
\hline 5. & $\begin{array}{l}\text { membabateng } \\
\text { semua kategori } \\
\text { (Ia4) }\end{array}$ & $\begin{array}{l}\text { opponent/people } \\
\text { thing } \\
\text { grass }\end{array}$ & outdo \\
\hline 6. & $\begin{array}{l}\text { menyabet 29 } \\
\text { emas (Ia5) }\end{array}$ & $\begin{array}{l}\text { medal } \rightarrow \\
\text { people/things }\end{array}$ & win \\
\hline 7. & $\begin{array}{l}\text { kejutan besar } \\
\text { ditorehkan }(\mathrm{Ib} 2)\end{array}$ & $\begin{array}{l}\text { winning } \rightarrow \text { latex, } \\
\text { sap }\end{array}$ & got \\
\hline
\end{tabular}

Table 2

English Anthropomorphic Metaphors

\begin{tabular}{|l|l|l|l|}
\hline No. & Expression & $\begin{array}{l}\text { The Change from } \\
\text { Referent } \rightarrow \\
\text { Symbol }\end{array}$ & Meaning \\
\hline 1. & $\begin{array}{l}\text { societal } \text { shift } \\
\text { (Ea6) }\end{array}$ & people $\rightarrow$ thing & slight change \\
\hline 2. & $\begin{array}{l}\text { a push toward } \\
\text { gender quality }\end{array}$ & $\begin{array}{l}\text { quality } \rightarrow \\
\text { concrete thing }\end{array}$ & motivation \\
\hline
\end{tabular}




\begin{tabular}{|c|c|c|c|}
\hline & (Ea7) & & \\
\hline 3. & $\begin{array}{l}\text { give himself a } \\
\text { shot (Eb1) }\end{array}$ & game $\rightarrow$ battle & play \\
\hline 4. & $\begin{array}{l}\text { shot up the } \\
\text { ranking (Eb3) }\end{array}$ & game $\rightarrow$ battle & get higher rank \\
\hline 5. & $\begin{array}{l}\text { It was neck and } \\
\text { neck }\end{array}$ & $\begin{array}{l}\text { nerveous } \rightarrow \\
\text { human body }\end{array}$ & nervous \\
\hline 6. & $\begin{array}{l}\text { maiden World } \\
\text { Sperseries } \\
\text { (Eb13) }\end{array}$ & event $\rightarrow$ people & First event \\
\hline 7. & $\begin{array}{l}\text { edged past } \\
\text { Denmark' Mads } \\
\text { Pieler (Eb15) }\end{array}$ & people $\rightarrow$ thing & outdo \\
\hline 8. & $\begin{array}{l}\text { a stunning } \\
\text { performance } \\
\text { (Ec2) }\end{array}$ & game $\rightarrow$ fight & good \\
\hline 9. & $\begin{array}{l}\text { by sweeping } \\
\text { their ... (Ec3) }\end{array}$ & $\begin{array}{l}\text { opponent/people } \\
\rightarrow \text { unused thing }\end{array}$ & outdo \\
\hline 10. & $\begin{array}{l}\text { the other wins } \\
\text { came (Ec5) }\end{array}$ & $\begin{array}{l}\text { winning } \rightarrow \\
\text { human/animal }\end{array}$ & win the game \\
\hline 11. & $\begin{array}{l}\text { they moved to } \\
\text { second place }\end{array}$ & winning $\rightarrow$ place & $\begin{array}{l}\text { become the } \\
\text { second winner }\end{array}$ \\
\hline 12. & $\begin{array}{l}\text { on the } \\
\text { provisional } \\
\text { standing }\end{array}$ & $\begin{array}{l}\text { winning } \rightarrow \\
\text { position }\end{array}$ & winning \\
\hline
\end{tabular}

Non-metaphoric expressions (in meaning column) describe the semantic relationship between referent and symbol clearer. The meanings are drawn based on the context of each expression and the shared semantic features between metaphoric and non-metaphoric expressions or symbol and referent as shown in the following examples:

(1) menyingkirkan unggulan pertama (Ib3)

(2) defeating the seed no 1 
Indonesian and English Lexical Metaphoric Expressions Used In Online Competition News Text

"Getting rid of the seed no 1"

- Throwing something away

- giving no chance

to play in the next round

- Done with effort

- done with effort

- The thing moves from the previous place - the team leave the next round

Menyingkirkan "getting rid of" is said to symbolize defeating because of those similar semantic features.

Opponent/people $\rightarrow$ thing dominates symbolization of metaphors of this kind. The symbol used are singkirkan (Ib1), menyingkirkan (Ib3), menggeser (Id3). The meaning conveyed is to defeat/to outdo/to win. Again, the defeated team is seen as the victim. The same symbolization is also often used in English. The used symbols are societal (Ea6), edged past (Eb15), and sweeping (Ec3).

The symbols which may be typical are membabat (Ia4), menyabet (Ia5), ditorehkan (Ib2). This is due to the relationship between all those expressions with agricultural setting of community life, which is still dominant in Indonesia. Meanwhile, some English metaphoric expressions are closed to their modern tradition. It can be seen from the use of shot (Eb1) and shot up (Eb3) which employ such modern tool as gun. The same symbols are not found in Indonesian online compettition news.

\section{Animal Metaphors}

Metaphors of this kind can be seen from the examples in table 3 and 4 below:

Table 3: Indonesian Animal Metaphors 


\begin{tabular}{|c|l|l|c|}
\hline No. & Expression & $\begin{array}{l}\text { The Change from } \\
\text { Referent } \rightarrow \\
\text { Symbol }\end{array}$ & Meaning \\
\hline 1. & $\begin{array}{l}\text { menunjukkan } \\
\text { taringnya } \text { (Ia1) }\end{array}$ & team $\rightarrow$ animal & good play \\
\hline 2. & $\begin{array}{l}\text { taring itu } \\
\text { ditunjukkan (Ia2) }\end{array}$ & team $\rightarrow$ animal & good play \\
\hline 3. & $\begin{array}{l}\text { mengincar } \\
\text { kemenangan (Ia6) }\end{array}$ & winning $\rightarrow$ prey & pursue \\
\hline 4. & jadi incaran (Ia7) & winning $\rightarrow$ prey & pursue \\
\hline 5. & $\begin{array}{l}\text { memburu } \text { nomor } \\
\text { individual (Ic6) }\end{array}$ & winning $\rightarrow$ prey & pursue \\
\hline
\end{tabular}

Table 4

English Animal Metaphors

\begin{tabular}{|l|l|l|l|}
\hline No. & Expression & $\begin{array}{l}\text { The Change from } \\
\text { Referent } \rightarrow \\
\text { Symbol }\end{array}$ & Meaning \\
\hline 1. & $\begin{array}{l}\text { flying regionally } \\
\text { (Ed2) }\end{array}$ & team $\rightarrow$ animal & play \\
\hline 2. & $\begin{array}{l}\text { a hawk in flight } \\
(\text { Ed3 })\end{array}$ & team $\rightarrow$ animal & team \\
\hline
\end{tabular}

From the data in the two tables, it may also be concluded that Indonesian animal metaphors are dominantly pertaining to hunting. Such symbols as taring (Ia2)/taringnya (Ia1), mengincar (Ia6)/incaran (Ia7), memburu (Ic6) are closed to the natural way of live. Meanwhile, English has fly (Ed2) and hawk (Ed3), cooccured with flight (Ed3) which are may be seen as having correlation with technology or modern way of life. 
Indonesian and English Lexical Metaphoric Expressions Used In Online Competition News Text

\section{Synesthetic Metaphors}

Table 5 and 6 below summarize synaesthetic metaphors that express game processes and results in online competition news.

Table 5

Indonesian Synaesthetic Metaphors

\begin{tabular}{|c|c|c|c|}
\hline No & Expression & $\begin{array}{l}\text { The Change from } \\
\text { Referent } \rightarrow \text { Symbol }\end{array}$ & Meaning \\
\hline 1. & $\begin{array}{l}\text { pertandingan } \\
\text { digelar }(\mathrm{Ia} 3, \mathrm{Ib} 8)\end{array}$ & competition $\rightarrow$ mat & held \\
\hline 2. & $\begin{array}{l}\text { menundukkan } \\
\text { pasangan no. } 1 \\
\text { (Ib4) }\end{array}$ & to defeat $\rightarrow$ to nod & defeat \\
\hline 3. & $\begin{array}{l}\text { lolos dari pasangan } \\
\text { Tiongkok (Ib5) }\end{array}$ & $\begin{array}{l}\text { to win } \rightarrow \text { to save } \\
\text { from siege }\end{array}$ & win \\
\hline 4. & $\begin{array}{l}\text { diserang/menyeran } \\
g(\mathrm{Ib} 6, \mathrm{Ib} 7)\end{array}$ & competition $\rightarrow$ battle & play \\
\hline 5. & $\begin{array}{l}\text { ajang Word } \\
\text { Military } \\
\text { Parachuting } \\
\text { Championship (Ic1) }\end{array}$ & event $\rightarrow$ place & event \\
\hline 6. & $\begin{array}{l}\text { merebut medali } \\
\text { emas (Ic3) }\end{array}$ & $\begin{array}{l}\text { to compete } \rightarrow \text { to } \\
\text { fight over }\end{array}$ & win \\
\hline 7. & $\begin{array}{l}\text { medali } \\
\text { dipersembahkan } \\
\text { (Ic4) }\end{array}$ & medal $\rightarrow$ offering & given \\
\hline 8. & $\begin{array}{l}\text { Ni Putu mencatat } \\
\text { ketepatan } 0,57 \mathrm{~cm} \\
\text { (Ic5) }\end{array}$ & $\begin{array}{l}\text { to parachute } \rightarrow \text { to } \\
\text { note }\end{array}$ & $\begin{array}{l}\text { to parachute } \\
\text { to } 0,57 \mathrm{~cm}\end{array}$ \\
\hline 9. & $\begin{array}{l}\text { mengumpulkan } \\
\text { medali (Ic7) }\end{array}$ & $\begin{array}{l}\text { medal } \rightarrow \text { common } \\
\text { collection }\end{array}$ & win \\
\hline 10. & $\begin{array}{l}\text { merebut gelar juara } \\
\text { (Id4) }\end{array}$ & $\begin{array}{l}\text { to compete } \rightarrow \text { to } \\
\text { fight over }\end{array}$ & win \\
\hline 11. & $\begin{array}{l}\text { kegembiraan } \\
\text { terpancar (Id5) }\end{array}$ & happiness $\rightarrow$ light & $\begin{array}{l}\text { happy for the } \\
\text { winning }\end{array}$ \\
\hline 12. & mendulang 8 & winning $\rightarrow$ gold & win \\
\hline
\end{tabular}


Table 6

English Synesthetic Metaphors

\begin{tabular}{|c|c|c|c|}
\hline No & Expression & $\begin{array}{l}\text { The Change from } \\
\text { Referent } \rightarrow \text { Symbol }\end{array}$ & Meaning \\
\hline 1. & $\begin{array}{l}\text { earned a medal } \\
(\mathrm{Ea} 1,3,4,5)\end{array}$ & winning $\rightarrow$ earning & got \\
\hline 2. & $\begin{array}{l}\text { takes second place } \\
\text { (Ea2) }\end{array}$ & winning $\rightarrow$ position & $\begin{array}{l}\text { becomes the } \\
\text { second } \\
\text { winner }\end{array}$ \\
\hline 3. & $\begin{array}{l}\text { entering the men's } \\
\text { single final (Eb2) }\end{array}$ & game $\rightarrow$ room/place & Playing \\
\hline 4. & $\begin{array}{l}\text { stunned no } 4 \text { seed } \\
\text { (Eb4) }\end{array}$ & $\begin{array}{l}\text { to compete } \rightarrow \text { to } \\
\text { fight over }\end{array}$ & played \\
\hline 5. & $\begin{array}{l}\text { trailled for much of } \\
\text { (Eb5) }\end{array}$ & event $\rightarrow$ place/road & played \\
\hline 6. & $\begin{array}{l}\text { he stepped it up } \\
\text { (Eb6) }\end{array}$ & winning $\rightarrow$ ladder & won \\
\hline 7. & $\begin{array}{l}\text { to take the next six } \\
\text { points }(\mathrm{Eb} 7)\end{array}$ & $\begin{array}{l}\text { winning } \rightarrow \text { concrete } \\
\text { thing }\end{array}$ & to win \\
\hline 8. & $\begin{array}{l}\text { shot past his } \\
\text { opponent }(\mathrm{Eb} 9)\end{array}$ & $\begin{array}{l}\text { competition } \rightarrow \\
\text { battle }\end{array}$ & outdo \\
\hline 9. & $\begin{array}{l}\text { quelled Kento } \\
\text { Moonota (Eb10) }\end{array}$ & $\begin{array}{l}\text { competition } \rightarrow \\
\text { battle }\end{array}$ & outdo \\
\hline 10. & lost his way (Eb11) & play $\rightarrow$ track & played badly \\
\hline 11. & $\begin{array}{l}\text { earned a shot } \\
\text { (Eb12) }\end{array}$ & $\begin{array}{l}\text { competition } \rightarrow \\
\text { battle }\end{array}$ & play \\
\hline 12. & $\begin{array}{l}\text { a title clash with } \\
\text { (Eb14) }\end{array}$ & $\begin{array}{l}\text { to compete } \rightarrow \text { to } \\
\text { fight over }\end{array}$ & play \\
\hline 13. & $\begin{array}{l}\text { Indonesia beats } \\
\text { Armenia (Ec1) }\end{array}$ & $\begin{array}{l}\text { to compete } \rightarrow \text { to } \\
\text { fight over }\end{array}$ & outdoes \\
\hline
\end{tabular}


Indonesian and English Lexical Metaphoric Expressions Used In Online Competition News Text

\begin{tabular}{|c|c|c|c|}
\hline 14. & $\begin{array}{l}\text { their latest victim } \\
(\mathrm{Ec} 4)\end{array}$ & $\begin{array}{l}\text { to compete } \rightarrow \text { to } \\
\text { fight over }\end{array}$ & opponent \\
\hline 15. & $\begin{array}{l}\text { Indonesia pounded } \\
4-0(\mathrm{Ec} 8)\end{array}$ & $\begin{array}{l}\text { to compete } \rightarrow \text { to } \\
\text { fight over }\end{array}$ & won \\
\hline 16. & $\begin{array}{l}\text { true test came in the } \\
\text { third round }(\mathrm{Ec} 9)\end{array}$ & play $\rightarrow$ test & good play \\
\hline 17. & $\begin{array}{l}\text { beating Romania } \\
\text { (Ec10) }\end{array}$ & opponent $\rightarrow$ victim & outdoing \\
\hline 18. & $\begin{array}{l}\text { the lead up to the } \\
\text { third round (Ec11) }\end{array}$ & competition $\rightarrow$ track & play \\
\hline 19. & $\begin{array}{l}\text { given the } \\
\text { opponent's line up } \\
\text { (Ec12) }\end{array}$ & competition $\rightarrow$ track & chance \\
\hline 20. & $\begin{array}{l}\text { Medina was } \\
\text { outstanding over } \\
\text { Foisor (Ec13) }\end{array}$ & $\begin{array}{l}\text { winning } \rightarrow \\
\text { reputation }\end{array}$ & win over \\
\hline 21. & $\begin{array}{l}\text { taking three wins } \\
\text { (Ec14) }\end{array}$ & $\begin{array}{l}\text { winning } \rightarrow \text { concrete } \\
\text { thing }\end{array}$ & getting \\
\hline 22. & $\begin{array}{l}\text { the team challenged } \\
\text { China (Ec15) }\end{array}$ & $\begin{array}{l}\text { to compete } \rightarrow \text { to } \\
\text { fight over }\end{array}$ & played \\
\hline 23. & $\begin{array}{l}\text { first place honour } \\
\text { (Ed1) }\end{array}$ & winning $\rightarrow$ place & $\begin{array}{l}\text { becomes the } \\
\text { first winner }\end{array}$ \\
\hline 24. & $\begin{array}{l}\text { a top place to be } \\
\text { for .... (Ed4) }\end{array}$ & winning $\rightarrow$ place & $\begin{array}{l}\text { becomes the } \\
\text { first winner }\end{array}$ \\
\hline 25. & $\begin{array}{l}\text { KU team placed } \\
\text { first in .... (Ed5) }\end{array}$ & winning $\rightarrow$ place & won \\
\hline 26. & $\begin{array}{l}\text { a first place award } \\
\text { (Ed6) }\end{array}$ & winning $\rightarrow$ place & winning \\
\hline
\end{tabular}

Most of metaphoric expressions found both in Indonesian and English online competition news are antropomorphic. The symbolization of competition as fighting or battle is dominant in those two languages. It is shown by $42 \%$ of Indonesian and $42.3 \%$ of English metaphors. The symbols used are lolos (Ib5), 
diserang/menyerang (Ib6, Ib7), merebut (Ic3, Id4), stunned (Eb4), shot (Eb9, Eb12), quelled (Eb10), clash (Eb 14), beats (Ec1), victim (Ec4), pounded (Ec8), challenged (Ec15).

\section{Conclusion}

The conclusions may be made based on the data analysis in the previous part are: (1) metaphoric expressions are used to intensify meaning, to represent the writer's sense of things being described, (2) metaphoric expressions used in the online competition news falls into three cathegories, i.e. Anthropomorphic, animal, and synesthetic metaphor, (3) metaphoric expressions used in the online competition news are tightly related to the way the writer sees the phenomenon, which is influenced by cultural aspects of the writer. 
Indonesian and English Lexical Metaphoric Expressions Used In Online Competition News Text

\section{References}

Crystal, David. 1993. The Cambridge Encyclopedia of Language. Cambridge: Cambridge University Press.

Deddy Mulyana dan Rakhmat Jalaluddin. 1996. Komunikasi Antarbudaya. Bandung: Penerbit PT Remaja Rosdakarya.

Edi Subroto, D. 1986. Semantik Leksikal I. Surakarta: Universitas Sebelas Maret.

Eggins, Suzanne.1994. An Introduction to Systematic Functional Linguistics. London: Pinter Publisher.

Fairclough, Norman. 1989. Language and Power. New York: Longman Group Ltd.

Hatch, Evelyn dan Cheryl Brown. 1995. Vocabulary, Semantics and Language Education. Cambridge: Cambridge University Press.

Hodge, Robert dan Gunther Kress. Language as Ideologi. London: Routledge.

Johnson, Wendell Stacy. 1972. Words, Things and Celebrations. Harcourt Brace Javanovich Inc.

Mansoer Pateda. 1998. Semantik Leksikal (ed. kedua). Jakarta: Penerbit Rineka Cipta.

Morgan, Jeffy L. 1980. "Observations on the Pragmatics of Metaphor", dalam Metaphor and Thought (ed. Andrew Ortony). Cambridge: Cambridge University Press.

Pangestuti Wiedarti. 1997. "Ragam Bahasa Jurnalistik dalam Rubrik Konsultasi Seksualitas", dalam Ragam Jurnalistik dan Pengajaran Bahasa Indonesia (ed. Sudaryanto dan Sulistiyo). Semarang: Citra Almamater.

Richards, Jack, John Platt and Heidi Weber. 1990. Longman Dictionary of Applied Linguistics. Harlow: Longman Group Limited.

Sampson, Geoffrey. 1980. School of Linguistics. London: Hutchinson \& Co. Ltd. 